\title{
The concept of "dialogical soul" by Joseph Ratzinger against the latest concepts of neuroscience
}

\section{MONIKA SZETELA, GRZEGORZ OSIŃSKI}

College of Social and Media Culture in Torun

monika.kacprzak@wsksim.edu.pl

grzegorz.osinski@wsksim.edu.pl

...Simple is true, and true is a simple

Benedict XVI

The extraordinary complexity arises from the deep simplicity

Murray Gell-Mann

\begin{abstract}
The concept of the dialogical soul proposed by Joseph Ratzinger is a contemporary attempt to describe the anthropology of humanity in terms of basic, fundamental theological concepts. Epistemological approach of the dialogic soul is not about the division, but co-existence in the concept of humanity significantly different anthropological concepts. Modern neuroscience, although following completely different paths of knowing is currently concerning an important issue "of the embodied mind". Such a holistic effort to discover the truth about the man, though carried out on completely different epistemological platforms, however, have some points in common. The difficulty in finding a common language for the dialogue in this field can be overcome and lead to dialogue, which is extremely difficult but doable. We must, however, at the beginning formulate certain fundamental axioms that define class concepts used in
\end{abstract}


different areas of scientific activity. The concept of dialogical soul of Ratzinger's now exceeds the barrier of scientific paradigms axioms. It does not stop on the vision of human oneself, but recognition of one in the area of relationships and makes room for a substantial dialogue with the world of modern science.

Key words: dialogical soul; neuroscience; consciousness; anthropology; ontological relations.

\section{Introduction}

The examination of theological issues in terms of modern scientific paradigm seems today the exotic concept. Not always, however, it was that way, modern science has clearly deviated from its original roots and lost its main purpose, which is to seek the truth about the man and reality. We offer a kind of "return to the past", but not to the historical concepts and attempts to describe the world, but to the universal role of science in learning about the world in general. The return to the original concept of Musejon-School of Alexandria-seems necessary today, to prevent the present in contemporary scientific paradigm, injecting uncomfortable facts in the realm of fiction, or the vision of the researcher, and the imposition of winding and murky classification and nomenclatures (Baggott 2013, 366-369). The return to the roots meaning the inquiry of the essence of being and the world of ideas both by Plato and Aristotle.

Modern technology has allowed the unimaginable broadening of horizon of knowledge. Well, however, on the occasion high specialization of scientific disciplines was made at the same time that any reasonable model of the overall recognition of important issues is virtually impossible. And humanity is faced with a very serious issue which must be coped - to define the essence of humanity. Upcoming technology interference in the structure of the human brain, copying the contents of the natural neuronal correlates and biotechnology allow us to create entities that in the classic terms stop to be a man, but will probably claim a different place in the structure of societies and it will not be a human helper role.

That is why modern science must be embed in living tissue of problems of the present world. Problems in which the subject is a man, and not abstract 
ideas. The danger of technocracy in conjunction with transhumanism can dismantle the structures of the modern world in a way that is unimaginable. We cannot afford to state that we still have time because technology has not solved some problems. Although this sounds pessimistic, however, it seems that the domination of reductionist scientific paradigm had already lost the ability to analyze the structures of reality.

The task of modern science has ceased to be the penetration in the essence of things, inquire "how it really is", but directing the entire activity on the confirmation of the compliance with the experience ${ }^{1}$.

In this study we try to indicate a new possibility by a conceptual return to Alexandrian Musejon, and the concept of "dialogical soul" presented in 1977 by Joseph Ratzinger seems the best concept, which is able to combine the two, separable today, worlds of intellectual activity of man.

\section{The crisis of science, crisis of anthropology}

Modern science has found itself on the brink of a serious crisis, which by Jim Baggott was referred to as "farewell to reality". Scientific hypothesis become by its terms "science fantasy", in which the methodology of scientific work has been replaced by concepts, though extremely attractive, but from a practical point of view, unsourced (Baggott 2013, 37-43). Other researchers point to the very serious crisis in the field of the humanities, which begin to lose contact with the basic anthropological concept of human, culture or society. Andrzej Zybertowicz, in the book under the significant title

\footnotetext{
Only recently we can go beyond the empirical methodology, we no longer only rely on designing and carrying out experiments. We can return to try a holistic insight into the test of reality, using the technology to fit the constructed image to our human visual perception system. Not only can we collect huge collection of accurate information from the surrounding reality, even virtualize it. We also have the ability to analyze and merge large collections of information far beyond the existing reduction methods that describe the "slices" of the world. Previously we shared the analysis of the data, depending on the specific division of scientific disciplines, the maps were associated with geography, charts with economy, iconography with sociology. We are learning now, and with more and better effects, to analyze the entire, unpartitioned before world. It is not yet a perfect approach, but undoubtedly a good step in the right direction.
} 
“Suicide of Enlightenment" (Zybertowicz 2015, 115-137) in a very accurate way analyzes the situation in the field of social sciences. Methodology for deconstructing the concept of humanity has led not only to the ethical crisis in many areas, but reserves the right to determine the moral norms in terms of scientific methodology.

Uncritical use of modern technology has led the universalist model of science to degeneration that leads only to applying useful methods. N. Taleb called this modern trend "technoscience" (Taleb 2012, 255-259), and its roots are not seen in the correct application of the scientific method, but in ideological pursuit of dominance of groups with both the financial resources and the huge political influence. In his work the modern methodology is specified as the "School of the Moscow-Harvard" of clearly ideologically leftist deviation. In science it accepts only those concepts and methods that confirm the recognition of the contemporary ideological "science managers". But should the main purpose of science not be something completely different? "After all, the hallmark of any scientific research should be wisdom, best overall including the society as a whole, although not always such a state of affairs would correspond to the politicians. Is wisdom to catch the essence of things? And what this «essence» is - just a construct of mind resulting from viewing and analysis or the real component of the surrounding reality" (Osiński 2015, 18-43).

Marxist and neo-Marxist science concepts dominate in today's trends of European science. A typical representative of the mainstream, the sociologist Pierre Bourdieu in his numerous works (Practical reason. On the theory of action, Pascalian Meditations), though he was an opponent of the neo-liberal offensive, shows the world of scientists of modern universities in terms of his theory of symbolic violence ${ }^{2}$. The basic question concerning our further

\footnotetext{
Bourdieu makes a specific class division of the scientific world, offering by the way the elimination of any foundations embedded in systems of the highest value. Rejects the dogmatics and describes the world of scientists in the spirit of classical Marxism with the inherent element of aggression in the form of class struggle. They are trully classes developed much since the days of the classic description of Marx and placed in the newly defined fields of power or culture, and replaces the classic capital with the cultural and symbolic capital, but the spirit of the split here is extremely visible.
} 
considerations becomes whether such scientific community, consisting of men, after all, scientists - is able to describe, investigate and define the basic problems modern science faces? Whether the disruption and the atomization of the individual scientific trends, hidden in their narrow sections, fields, and properly "shelves" allows to research any logical synthesis, that can face the next challenges of the modern world?

In such a landscape, the vast offensive of neuroscience representatives who enter the area reserved until now for the humanities with a powerful arsenal of empirical measures allowing to conduct studies directly on the brain of a living man, and verify the results on the many existing theoretical concepts, should arouse concern. The study of the human brain, in paradigm of these sciences, are directly transferred to the conceptual ontologies relating directly to the most important elements that define the man. Progress in this area is huge, often described with a hermetic specialists language and largely incomprehensible to other specialties.

Michał Heller warns against the dangers menacing today teachings of theology: "[...] going back to the trouble of theological interpretation of new scientific data, I will say something more: at the moment there is a huge improvement in the field known in English as neuroscience, dealing with the functioning of the brain, the process of creating images, the essence of consciousness, the ability of artificial intelligence, the problem of the relationship of the mind to the brain (mind-body problem). I predict that if there was the case of Galileo, there is the case of Darwin, sooner or later there will be the case of neuroscience. If the Church does not prepare for it, the crisis even greater than at the time of Galileo is ahead of us. The Church should educate legions of specialists right now. Otherwise we will stay in antediluvian times in theology. Besides facing the new challenges can make theology become a fascinating field for the modern man" (Duch 2010, 140).

Does theology take any action steps to stave off the current crisis? It seems that the concept of J. Ratzinger concerning the dialogical soul perfectly fits into this theme. But has it been appropriately popularized 
and has an honest dialogue on this subject been led with representatives of "technoscience" ? This study is the attempt to answer such questions.

The issue taken by us derives from attempts to redefine person, we have to oppose. Experiments carried out successively affect each of the attributes of humanity. Let the problem of redundancy of the concept of the soul by the representatives of neuroscience serve as an example. Alison Gopnik writes bluntly: "Well, I believe that one day the problem of Consciousness (with capital C) will disappear in the same way as a problem of Life ceased to exist in the Biological Sciences". So with such attitude of the world of "technoscience" it is possible to lead any dialogue on the concept of the soul, when even the concept of "consciousness" and "life" seem unnecessary for them (Brockam 2008, 43-47)?

\section{Theology on the soul}

Theologians came to deal with the situation in which a biblical claim of unconditional inseparability of man confronted anthropology, shaped by the natural sciences, which considers only its corporeality. A professor at the University of Regensburg at that time - Joseph Ratzinger faced the problem. In the book Eschatologie-Tod und ewiges Leben ("Eschatology - death and eternal life") the issue of Catholic interpretation of the issue of the soul, immortality and resurrection has been discussed in detail. This book is considered the most comprehensive analysis of the said issues. Ratzinger emphasises two aspects of the theological inferences about human. First, he notes that the essence of humanity and of human life can be considered not only in the field of biological sciences. On the other hand, anthropological analysis based on the Scripture requires the rejection of "pure biblicism".

\footnotetext{
Although Nicholas Taleb believes it is the end-stage activity of this type of science, that the kind of "phase transition" of sudden change is coming, which in a way will sober scientific world. But these can be just dreams. You should take the effort to conduct a dialogue with the world of science in the language that will not be sealed for one scientific community. Let's not negate only argue. Let's look for the agreement, because only in such a way the crisis can be overcome and a creative discussion on the most important issues of man and civilization can be started.
} 
"Without the «hermeneutic» - says Ratzinger - that is, without reasonable thinking together with the biblical facts which may linguistically as well as in the systematic relation of thoughts go beyond facts from the Bible as such, you cannot accomplish anything” (Ratzinger 1988, 116-117).

The problem of the definition of the concept of the soul appears pivotal in our considerations, because even in everyday language the soul is often mistakenly associated with the human psyche. In the scientific world it also makes quite a lot of confusion. Martin Buber already drew attention to this issue, when he wrote that "the question of the soul" is destroyed, pushed to the margins or "inspired by Psychology, but it is not the philosophical or theological soul" (Ravasi 2008, 271).

Before we present the concept of the dialogical soul let us dwell on biblical hermeneutics, which forms the basis of theological considerations.

\section{The biblical account of the soul}

Recognition of the soul by Ratzinger that is the interest to us, has its philosophical grounding, but references to Plato and Aristotle are well known and we will not deal with them. While the understanding of theological sources, deriving from the biblical text requires recalling of the concept of language formulated by Hans Walter Wolff. By analyzing the biblical expression endearing human condition it is necessary today to have awarness of not only the time distance between the shown reality and the modern language, but above all to understand the fundamental difference between the presentation of phenomena, things, and events in Eastern culture and culture of Europe.

In the Bible there is no opposition existing in the Hellenistic world between body and mind/soul (Wagner 2016). When trying to read the symbolism of these concepts, you need to specify their functions, which is clarified by the context of the statement. H.W. Wolff calls the process of reading "synthetic spectrum of meaning" (Wolff 2002, 107). It is necessary to remember that named parts of the body express more than literal content, so they must be interpreted in view of the functions, capabilities and 
wholeness" (Wolff 2002, 108). Similarly, modern science should approach the problem of recognition of man- as a whole, rejecting the reductionism. It has a whole spectrum of examples of searching for beautiful solutions provided holistic approach, especially in the light of the application of the methodology of nonlinear dynamic systems (Stewart 2012, 112-114).

Holistic approach of man has its origins in the book of Genesis 2.7 "then the Lord God formed man of the dust of the ground and breathed into his nostrils the breath of life, and the man became a living being".The expression used "living being - nefesz hajjah" not only means the soul but the entire spectrum of designating characteristics of humanity. G. Ravasi explains: "Let's gather all elements, which our verse provides, to compose a portrait of a man. He has been "formed" of the dust of the ground, this is adam, because it is taken from adamah; the origin makes him limited and transient as a matter; this is basar - body to use biblical language, fragile and temporary. However, he receives the breath of life, ruah, the spirit, that puts him on the level of living creatures. The man has another dimension received from the Creator, that in a way links them: he is niszmat-hajjim, a living consciousness, consciousness of himself, the ability to distinguish the good from the bad, the freedom of moral choice. With these three essential components - in Hebrew, expressed using the words basar, ruah, neszamah/ niszmat - we have nefesz hajjah, meaning living person, the man”. (Ravasi 2008, 97).And as it is stressed by Ravasi, human uniqueness, involves not only the possession of consciousness, but it must also be seen in the ability to love ${ }^{4}$ (Ravasi 2008, 102).

4 In first book, Einführung in das Christentum (Introduction into Christianity) published in 1968, Ratzinger wrote: "from the Christian faith we conclude, therefore, that man becomes the most not by what he does, but by what he receives. He must wait for the gift of love and could not get love differently than as a gift. It cannot be «made», without the other; it has to be waited for, let it be given. And it is possible to become completely man only by being loved and letting to be loved. The fact,that love is the highest human possibility, and also the deepest need, and that what is the most essential and at the same time the most complete freedom given voluntarily, it just means that a person can count on his «Salvation» by the fact, that it is given to him. However, if one does not allow to be gifted that way, loses oneself. The activity absolutisating itself, that wants to give «being human» off itself, is in contradiction with the essence of the man" (Ratzinger 1994, 107). 
The phrase psyche used in the New Testament, translated most commonly as a soul ${ }^{5}$, goes beyond the Greek understanding of the spiritual and immortal soul. It is the most commonly used for the determination of the whole person (cf. Mt 12.18; Mt 22.37; Lk 12.20; Lk 21; 19; Ac 20.10; He 10.38; Ap 8.9) rather than an ethereal Platonic soul. It is clearly underlined, that the human person is at the same time, physical and spiritual being. This distinction does not, however, introduce the classical dualistic interpretation, it rather offers a unified construct in which different elements can be distinguished.

\section{Ratzinger's concept of dialogical soul}

Let us return to eponymous dialogical soul presented by Ratzinger. The biblical concept of soul shows us that there is no existence of a soul without a body. Therefore, any aspect of humanity cannot be underestimated and forgotten in scientific work. The soul is associated with the body, and not only with the abstract, immortal part of man existing autonomously in the "space of humanity". "The separation of the soul from the body is against its nature and reduces its resemblance to God the Creator. The existence in the body is not an act, but the self-realisation of the soul. The body is perceptivity of the soul, as the reality of the body is the soul" (Ratzinger 1988, 151). Ratzinger draws attention to two aspects of the immortality of the soul existing from the beginning in the teaching of the Church:

- it is designated by the "Christological means", which guarantees the indestructibility of life of believers in Christ;

- refers to the Hebrew idea of Sheol, the idea, which is based on the universal human idea of life after death.

What's more, in the teaching of the Church "tradent ${ }^{6}$ living with Christ, undamaged by the death the human person, is called, as in Judaic tradition,

5 "The concept of the soul often means in the Scriptures human life or the whole human person. It also means everything what in human is the innermost and most precious; what makes human be in most peculiarly the image of God: «soul» means the spiritual principle in human” (Katechizm Kościoła Katolickiego 2009, 363).

6 "One who is responsible for preserving and handing on the oral tradition, such as a teacher or preacher or missionary, in the form of apophthegms or similar pericopae" (A Dictionary of the Bible, 2016). 
the soul or spirit. (...) both these concepts were blacked out by the widespread Gnostic systems, in which psyche (soul) was classified as a low level of human being in contrast to existence of «pneumatics»" (Ratzinger 1988, 149).

A task which appeared to the philosophers and thinkers together with the incarnation, death and resurrection of Jesus Christ has occured very difficult. “(...) The Christian faith - Ratzinger marks - itself made certain demands upon anthropology, and these demands were not met by any of the preexisting ways of understanding what it is to be human. Nevertheless, the conceptual tools of such earlier anthropologies could and must be placed in the service of the Gospel by way of an appropriate transformation. What needed to be developed was an anthropology which in the first instance recognized that man is, in his unified totality, the creature of God, conceived and willed by him. But at the same time, this anthropology was also obliged to distinguish within man between an element that perishes and an element that abides-though in such a way that the path towards the resurrection, the definitive reunification of man and creation, remained open" (Ratzinger 1988, 149).

Similarly to the concept of "the mind embodied", dualism is here the qualitative imbalance of different aspects of humanity, the body is "running out", while the soul seeks for God. It is not yet spiritual disintegration. Difficult for the man, the revealed truth of the resurrection of the body, which, after all, in our reality becomes totally destructed naturally, seems unattainable. Ratzinger recalls, however, that it is God himself who supports from the perishability, "watching God" is not done by philosophical speculation, but the purity and simplicity of heart: faith and love - this is the basis for dialogical concept of existence. "Only God incarnate can draw us out of the waters by his power and hold us firm. Only he can make us stand up straight on the breakers of the sea of mortality. His promise is that we will attain the vision of God, which is life, not through speculative thinking but by the purity of an undivided heart, in the faith and love which take the Lord's hand and are led by it" (Ratzinger 1988, 152).

The role of consciousness cannot be forgotten in this discussion. The man is a conscious being, endowed with free will of choice of good and evil, 
capable of conscious behavior, action and activity. And this awareness is of crucial question concerning humanity. However, modern science does not offer us a commonly acceptable definition of consciousness which does not prevent it to deny the existence of free will. Apparently, a Nobel Prize winner Eric Kandel, put it, stating clearly: "If our choice is determined in the brain before we consciously decide, in that case, where is our free will? Maybe it is just an illusion, the rationalisation of our actions, after they have already been taken" (Kandel 2008, 15).

\section{Concepts of neuroscience}

Man is the essence of the overall, even in the most extreme streams of neuroscience all agree that the duality of the brain and the body is absolutely unacceptable. The human brain, removed from human and sustained alive in some hypothetical lab tank - in theory there are already such opportunities - will not work as a "human brain". Currently, the most important concept in neurosciences is "the embodiment of mind" (Mazur et al. 2011, 32-43). Isolated brain cannot be considered - despite its enormous complications brain is inside the human body - is a component of the system. The mind as a product of the brain is also embodied.

Theories of consciousness are very different, scientific world has not developed one widely acceptable theory of consciousness. However, if you define consciousness as a comprehensive collection consisting of the human intellect, memory, feelings, natural language and the ability to communicate with itself seems to be a consistent and fully defining the essence of humanity. Ratzinger, building on the legacy of Thomas Aquinas, explains it this way: in anima, which, as we have heard, on the one hand, belongs completely to the material world, on the other hand, however, exceeds this world over itself, the material world comes to itself just by the fact that the anima in man reaches to God by turning man to God all strands of natural levels and degrees of value return to its source. In this way, the person is conceived as being capable and called to know and love God. In this way, the dialogical concept is adopted, which grew out of the Christological vision 
of the human being and is linked with the problem of matter, the dynamic unity of the whole created world.

The concept of dialogical soul by Ratzinger exceeds above human recognition in consciousness described above, because does not stop on the human vision of himself, but recognition of him in the area of relationships. Thereby, not denying the achievements of neurosciences he sees the essence of humanity, on one hand, more broadly, by entering in the essentially major communication with God. On the other hand, deeper, because by source, indicating the origin of man as such inscribed in God.

The core of the essence of humanity lies in its referral to the full knowledge of the truth of God and thus rooted in the life. As Ratzinger notes, Teilhard de Chardin said, that the essence of evolution is to create better eyes. By taking it, you would say that man is the degree of creation, a creature whose essence should be the ability to see God (that is, the ability for the truth in the broad sense), and thus the opportunity to participate in life. "And it is neither speculation, or reductionism, Ratzinger sees human openness and ability to rooting in God this way. This possibility is the depth of the human being and it is called the "soul" (Ratzinger 1988, 154).

Ability to build relationships and reference to God as an expression of the depths of human existence implies openness to the whole being, to ourselves, to being a person. Otherwise, the man lives at odds with himself, negates their capabilities. The essence of the Ratzinger's concept of the soul is by the author himself stated as follows:

1. God is a relationship of love, is life. The relationship, openness makes immortality, not closing in itself. ${ }^{7}$ Living life with Jesus means

\footnotetext{
"Immortality cannot be accounted for in terms of the isolated individual existent and its native capacities, but only by reference to that relatedness which is constitutive of human nature. This statement about man returns us once again to our image of God, throwing light as it does so on the Christian understanding of reality at its central point. God too possesses immortality, or, more correctly, he is immortality, being that actuality of relationship which is Trinitarian love. God is not «atomic»: he is relationship, since he is love. It is for this reason that he is life. In this perspective, the relationship of two people which is human love shines with the radiance of the eternal mystery. The signal we derive from this view of being tells us: relation makes immortal openness, not closure, is the end in which we find our beginning" (Ratzinger 1988, 157-158).
} 
entering in His time, in the love that opens the eternity-transforming time.

2. Christian hope: a saved man as a unity and a whole person who matures in life on Earth.

3. The dialogue with God takes place through people (the community of the children of God effected in the body of Christ). God guides the dialogue in Christ - communio sanctorum, the inclusion in the Trinitarian relationship of the people of God (Ratzinger 1988, 159).

Ratzinger is of the opinion that eternal life is not due to the power of a single man, but constitutive relationship for him. Indicating the relationship with God here is also justified by the Trinitarian love of the Trinity. It is thanks to It human being enters into the mystery of the eternity. It needs to be noted, that such recognition of man also includes relationships between people. Theological concept of soul is open to wording that the dialogue between man and God continues through people and in people, lasts in specifically expressed history of the world.

"The crisis of the concept of the immortal soul, as well as the entire anthropological and eschatological thought in modern Christian theology, was attempted to overcome in various ways after Vatican Council II. The work of Joseph Ratzinger noticing the importance of the renewal of the traditional concepts and theological concepts also enters in this current significantly. Hence the latest search for Christian theological anthropology will later work as background of his contribution in discovering the truth about man, and especially - in the development of the renewed concept of the human soul" (Składanowski 2013, 61).

So is the dialogical soul the incarnation of the LOGOS in the human body, which reflection is the description of a universal language, that LOGOS can be describe? If it is, the appropriate language of the description should be sought. Natural language, though extremely prolific and flexible, does not allow us to describe many important processes that occur in the process of shaping the human mind. If we treat the mind as, on the one hand, the substantive function of the brain, on the other hand, as a kind of mirror reflecting the revealed truth, we need a different, dynamic concept of the 
soul. Therefore dialogical soul in addition to the concept of embodiment should also be seen in the context of the very definition of dialogue.

Dialogical soul is dynamic, and the dialogue expresses its structure in relation to ontic aspect. Its indestructibility does not derive only from the essence itself, but also from its structure. The basis for such thinking is properly understood psyche of man in terms of the dynamic model (Mazur and Osiński 2016,111-135). The structure of such a being must be antifragile, not to be the subject of destruction, but bending before even the most serious threats to return to its original form, in the sense of the dynamic conformation, after its retreat. Modern neurobiology through the concepts of the embodiment of mind as a function of the brain, is becoming closer to the concept. However, the way to the synthesis with theological concept is still very long, requires intensive and fruitful dialogue between these areas. It is a difficult process even within the specific science, let alone in such a delicate matter as the concept of the soul. Discovering the truth has never been easy, and the way to it, is marked by huge difficulties and sacrifices. However, we should take the struggle, because the man remains mystery to himself, and the greater it is, the more modern science looks at it.

\section{New opportunities for scientific dialogue}

Ravasi draws attention to the avoidance of the word "soul" and replacing the term with the expression "mind". Interchangeable use of the terms "inner life" and "spiritual life" can be added. This leads to a gradual fade of sensitivity to the important difference - the inner life is the expression of the emotional and cognitive state of consciousness of human being, while the spiritual life exists only in the relationship. In relationship to the spiritual being of God. The "wounded" transcendence of man through a limited perspective on the person, on experiencing humanity should be talked about.

The soul is overcoming oneself, satiation with goods and Eros (mentally and physically) is not enough - the overcoming oneself is the process of dynamic interaction with the world, however we understand it. Dynamic process of the overall system - not monads as in original concepts of 
Leibnitz's - is reciprocal action. A specific dialogue of the soul with the reality itself. The biggest problem from the point of view of modern scientific paradigm seems to be specification of the possibility of contact with reality itself. Perceptual system of embodied mind allows us to perceive only this part of reality, for which we can find representations in our mental space. The mind is no longer completely abstract being, it can be treated as a function of functional brain and it does not disturb anything. Epistemological approach of the concept of soul is not about separation, but its coexistence in the creation of the representation in the area of the mind. Such coexistence, with dynamic context is the dialogue, partly internal and partly outbound to face the world, for the embodied mind these activities do not have a major difference. Such dialogue can be conducted only granted with communing with revealed truth, we can only find in the teachings of Christ. The lack of such communication with the revealed truth leads though to full neural determinism. Fundamentally, it is no different from material determinism visible in concepts of eg. Descartes's, only dynamic space in which the processes take place is no longer a simple Cartesian space, but moves to a multidimensional configuration space, specified by the dynamic neuronal states. This is the way to one party only, another attempt to reduce the essence of humanity to the pre-defined framework of dynamic space. Only taking cooperation with revealed truth opens new development ways, removes schematic determinism and allows to discover new levels of humanity.

With today's state of development of the various fields of science the vision of not only the soul is changing but also the matter. "Comprehensive and dynamic vision proposed by evolutionism does not consider matter for static mass, inanimate, raw, static and passive, but considers it capable to participate, although to varying degrees and in its own way, in life paths of cosmic and being human,in its deep and constitutive dimensions, as endowed with energy and evolutionary potentiality. In other words, on immeasurable level of being, all realities, material and spiritual, are entered in a consistent and even the same manner (at least on the level of need), they are all bound by the common node that in religious vision is the manifestation of the divine works, and for the others - immanent action of Nature" (Ravasi 2008, 332). Still, 
however, a dualistic vision of man is firmly established in the common vision. There is a huge field of research ahead of researchers, not only elaboration of a consistent approach of man with all his ontological wealth, but it also has to be admitted, that not less task is to tell a modern man about himself.

\section{Conclusion}

The concept of dialogical soul can become very fruitful platform for discussion between representatives of different sciences. The analogies with the achievements of modern neuroscience are quite strong and a universal language of dialogue needs to be elaborated to find common points and lead to the identification of issues and common content. It will probably be very difficult to apply the language of mathematics, to, on the one hand, describe the complex dynamic structures and explain variable dialogue process. After all, it is not only about the exchange of opinions, but should also mutually affect the concepts presented by the parties of the dialogue. "Technoscience" admitted already by the mouth of the outstanding neuroscientist Marvin Minski to problems: "We lost the first 100 years of Psychology on trivial theories of how people learn and react in different situations. We return to the central issue of psychology. When considering not the situations, but types of issues." Is theology able to make a similar step towards representatives of science? The hope remains that this process will continue.

We are still at the level of hypotheses, determining the language of multidisciplinary dialogue, therefore, intelligibility of the concept of the mind, consciousness, soul by man cannot be talked about. It seems however, the range of common issues emerges, essential in the search for the truth about man.

\section{References}

A Dictionary of the Bible. 2016. "Tradent.” Accessed March 25 http://www.oxfordbiblicalstudies.com/.

Baggott, Jim. 2013. Farewell to Reality: How Modern Physics Has Betrayed the Search for Scientific Truth. London: Pegasus. 
Brockam, John. 2008. W co wierzymy, choć nie potrafimy tego dowieść. Warszawa: Smak Słowa.

Duch,Włodzisław. 2010. “Czy jesteśmy automatami? Mózgi, wolna wola i odpowiedzialność.” In Na ścieżkach neuronauki, edited by Piotr Francuz. Lublin: KUL.

Kandel, Eric. 2008. "Interview with Eric R. Kandel: From Memory, Free Will, and the Problem with Freud to Fortunate Decisions.” Journal of Visualized Experiments $15: 762$.

Katechizm Kościoła Katolickiego. 2009. Poznań: Pallottinum.

Mazur Roman et al. 2011. Chaos w głowie. Mózg i życie. Inowrocław: Aspektpress.

Mazur Roman, Osiński Grzegorz. 2016. Neurologia kiliniczna. Homeostat mózgu. Inowrocław: AspektPress.

Osiński, Grzegorz. 2015. "Wizualizacja informacji. Badania struktur informacji w poszukiwaniu prawdy." Fides Ratio et Patria 3.

Ratzinger, Joseph. 1988. Eschatology. Death and Eternal Life. Washington: The Catholic University of America Press.

Ratzinger, Joseph 1994. Wprowadzenie w chrześcijaństwo. Kraków: Znak.

Ravasi, Gianfranco. 2008. Krótka historia duszy. Kraków: Salwator.

Składanowski, Marcin. 2013. Ciało, dusza, duch. Myśl Josepha Ratzingera na tle współczesnej antropologii. Warszawa: Wydawnictwo Śióstr Loretanek.

Stewart, Ian. 2012. Dlaczego prawda jest piękna. Warszawa: Pruszyński.

Taleb, Nassim Nicholas. 2012. Antifragile. Things that gain from disorder. New York: Random House.

Wagner, Andreas. 2016. “Körper.” Accessed March 15. https://www.bibelwissenschaft. de/

Wolff, Hans Walter. 2002. Anthropologie des Alten Testaments. München: Gütersloher Verlagshaus.

Zybertowicz, Andrzej. 2015. Samobójstwo oświecenia. Kraków: Kacper . 